\title{
EDITORIALS
}

\section{Conservation to Aid Near East Settlement?}

When he appeared to be emerging as the acceptable negotiator in the Near as in the Far East, we sent to U.S. Secretary of State Dr Henry A. Kissinger the following cable:

STRONGLY URGE DUE CONSIDERATION BE GIVEN TO PRACTICABILITY OF CONSTITUTING DISPUTED ARAB TERRITORIES ESPECIALLY SINAI AS NATIONAL OR INTERNATIONAL PARKS ADMINISTERED BY COUNTRIES CONCERNED UNDER SUPERPOWERS GUARANTEE AND UNITED NATIONS TRUSTEESHIP CONFORMING TO THEIR STANDARDS FOR NATIONAL PARKS AND EQUIVALENT RESERVES / STOP / TO DATE ENTIRE [ERSTWHILE] UNITED ARAB REPUBLIC LACKS ANY AREA ATTAINING THOSE STANDARDS.

This we followed by an explanatory letter dated 15 December 1973 and by private discussions with concerned individuals. With rare exceptions they supported the suggestion, often enthusiastically, and certainly we stand by it.

The Arab countries primarily concerned are of course Egypt and Syria, which are very much behind the times in having no parks or reserves attaining the standards required for inclusion in the United Nations List of National Parks and Equivalent Reserves, whereas Israel, in spite of its limitations of territory, has no fewer than thirteen. Although Jordan and Lebanon have both for some years had plans for the establishment of national parks, the 1973 United Nations List indicates them both, like Syria and Egypt ('United Arab Republic'), as still having 'No areas qualify.' The same, incidentally, applies to Iraq and Libya. Surely this presents a challenging opportunity to our Arab friends quickly to catch up and ultimately to excell in a vital respect.

Conservation has already proved to be a unifying factor in many ways, commonly crossing national frontiers and idealogical boundaries, the attempted mating of adopted British and Soviet Giant Pandas being a case in point, and the world-wide work of IUCN and WWF providing many other more important ones. The conservation movement had its beginnings in the desire of men and women of goodwill in many lands to preserve the more striking forms of wildlife. It has now developed into-and must continue to grow as - a survivalist surge, particularly directed towards saving the environment. This means the environment and very habitats of Man and Nature, which cannot well be separated: to push the separation too far would endanger life on Earth-particularly human life. That is the message, 'writ large and clear' for all mankind to recognize.

National parks and nature reserves are a fine expression of the conservation movement. Starting just over a century ago, with Yellowstone in the United States, their development has gathered momentum to such an extent that there are now few enlightened countries without at least one area conforming to the necessary United Nations standards; most have two or more such 'Listed Areas.' These have many values, ranging from the aesthetic to the utilitarian -not to mention their enormous importance for scientific research. Moreover they can be a valuable mecca for tourists and a haven for unique genetic material. Already there are notable instances of their transgressing national boundaries, and even leading to reduction of international tensions. Thus large contiguous areas of the High Tatra Mountains, where their common frontier lies along the crest, have been turned by Czechoslovakia and Poland into national parks. This, according to the U.N. List, 'constitues a classic example of international cooperation in the establishment of National Parks in a national frontier area,' so that friction has given way to 'effective collaboration at both the scientific and tourist' levels. Collaboration should be further consolidated by the increasing realization nowadays of the importance of maintaining national parks and equivalent reserves as totally inviolable. International parks could be even more widely recognized than national ones as a common heritage of all mankind.

Could not reasoning along these lines provide the key to a lasting peace in the Near East? It is not for us to suggest precisely how and where such areas should be established; this would have to be worked out very carefully in an atmosphere of goodwill. But if the nations concerned could agree, with proper guarantees and administration we feel it could be done-and ardently hope something along these lines will be accomplished with the least possible delay.

N. P.

Environmental Conservation, Vol. 1, No. 1, Spring 1974-(C) 1974 All Rights Reserved-Printed in Switzerland. 